\title{
Consumer Perception Influence Toward Capital Budgeting Efficiency for Culinary Business in Bandung, Indonesia
}

\author{
Alya Aulivia Rohali and Raden Aswin Rahadi
}

\begin{abstract}
This research aimed to identify consumer perception which encompasses a consumer's impression, awareness, and consciousness toward satay Taichan product to conduct and support the capital budgeting efficiency. This research will be conducted in Bandung, Indonesia area with range age of respondent 15-45 years old. Internal data of company and factors from the consumer perception are used to design the questionnaire. Recent satay Taichan product variation used to get the ideal price and product toward consumer perception and their tendency why choosing the product. Consumer perception information is formed for capital budgeting and finding factors causing the tendency to choose the product variation. The most important factor from the findings of this research that used to create the new product variation for satay Taichan in Bandung is the quality of the product. for some current value for a few current packages already enough appropriate for the market. Differentiation between package and detail rationalization is very important for the consumer to create their choice. The financial and accounting forecasting will be make as a main source of capital budgeting efficiency decision.
\end{abstract}

Index Terms-Consumer Perception, Culinary Business, Taichan Product Packages, Capital Budgeting, Bandung.

\section{INTRODUCTION}

SME's (Small Medium Enterprises) is the most significant contributor to Indonesia GDP (Gross Domestic Product), it can prove that they can give $60 \%$ of the total GDP (Bank Indonesia, 2015). A usual problem faced by SME in Indonesia is creating particular offers using the ability to understand the market changes [1]. Meanwhile, in the food industry, innovation is considered as one of the most important factors to increase competitiveness [2]. Moreover, [3] said that firm performance could merely be improved by innovation when they are accompanied by substantial and effective transformation to the market presence of a firm (in response to consumer demand and market dynamics).

Services or products that meet consumer perceptions can encourage and support the success of its business [4]. After the consumer perceptions are successfully reached the market needs, balancing the cash inflow and outflow are essential for the entrepreneurs to ensure that [5].

Published on August 5, 2019

R. A. Rahadi is with the School of Business and Management, Institut Teknologi Bandung, Jl. Ganesha No. 10, 40132, Bandung, West Java, Indonesia (e-mail: aswin.rahadi@sbm-itb.ac.id).

Alya A. Rohali is with the School of Business and Management, Institut Teknologi Bandung, Jl. Ganesha No. 10, 40132, Bandung, West Java, Indonesia (e-mail: alya.aulivia@sbm-itb.ac.id).
Knowing the capacity and capability of a company through the report of cash inflow and outflow also can help the investors to make a decision [6].

A poor cash flow projection could make incapability for a company to support funding their project executions plan as a basis of project controls [7]. Meanwhile, the right cash flow projection support to managing the risk that might appear in the further plan and making a right decision [8].

\section{A. Consumer Perception}

Consumer perception can produce a long-term relationship between the brand and its consumer, as the final acquire to a colleague the brand with perceiving it as having elevated quality [9]. Consumer perception also can be identified through product-related and non-product related attributes. Product-related differ by service category or product, meanwhile, non-product related with external aspect of purchase or consumption, which are packaging or product appearance, price information, and user imagery [10].

a. Personal Psychology on Purchasing Food

According to [11] there are five steps considered when purchasing products or selecting services (1) problem identification (2) Information search (3) evaluation of alternatives (4) purchase and (5) post-purchase evaluation.

\section{b. Trend Influence on Consumer Perception}

The complexity of consumer food choices can be seen towards trends development, as a result of increasing differentiation between food choices on the one hand and increasing dynamics, complexity and heterogeneity that can be analyzed and turned into a source of competitive advantage food producers [12].

\section{B. Cash Flow Forecasting}

According to [13] the feasible cash flow management have an impact to the importance of obtaining loans or another money lending institutions and much more prioritizing to companies and lend their money that is able to show their forecasting periodic cash flow.

\section{NPV (Net Present Value)}

NPV assessments can be utilized to decide whether the business is attractive enough to be invested. If the NPV is negative, the impact on offer esteem will be unfavorable. On the off chance that the NPV was certain, the impact would be ideal. As an outcome, all we have to think about a specific proposition to make an accept-dismiss choice is whether the NPV is negative or positive [14].

\section{IRR (Internal Rate of Return)}

Internal rate of return or known as IRR is a method closely related to NPV and is also known as a discount rate which can make the NPV equal to zero. To find a single rate of return 
can be done by calculating using IRR that summarized the benefits of a project. [15].

\section{E. Payback Period}

The payback period frame is the period until all the money streams of a venture rise to its expense. The payback period frame rule is to take period frame is a defective model, mainly because it overlooks chance, cash time estimations, and cash streams past the cut-off points. [16]

\section{METHODOLOGY}

\section{A. Purpose and Scope of the Study}

This research aimed to identify consumer perception which encompasses a consumer's impression, awareness, and consciousness toward satay Taichan product to conduct and support the capital budgeting efficiency. The data collection is collected using online questionnaire distribution through social media and online chatting platform. Related to data collection, the respondent of consumer perception were focused in Bandung with the average age about 15-40 years old in Bandung city.

\section{B. Population and Sampling Size}

This research preferred to use quantitative approach because it will involve a huge amount of samples and respondents [17]. The sample population for this research is focused on people based in Bandung and specifically in Bandung with the average age range between 15-40. According to [18] when the sample size of the population above 100.000 is the 100 people by assuming a level of precision is $\pm 10 \%$ level of confidence will be $90 \%$, and $\mathrm{P}=0.1$.

From the sources of BPS (Badan Pusat Statistik) website in 2017, the total amount of the population around Bandung are 1.115.748 people. This sampling technique also supported by using Slovin method to be able knowing the amount of sample size [19], also the formula is :

Where :

$$
n=\frac{N}{1+N e^{2}}
$$

$n=$ Number of the sample

$\mathrm{N}=$ Number of the population

$\mathrm{E}=$ Number of Error

$$
\begin{gathered}
n=\frac{1.115 .748}{1+1.115 .748(0.1)^{2}} \\
n=\frac{1.115 .748}{11.158,48} \\
n=100
\end{gathered}
$$

Hence, the minimum of sample size for this research is minimum of 100 peoples with the total of the population around 1.115 .748 .

\section{Data Collection Method}

Type of technique in non-probability random sampling for this research is used convenience sampling, which subjects of the population are easy to reach and access by the researcher [20]. It is mandatory for researchers to describe how samples will be different from those randomly selected. It is also important to describe subjects that may be excluded during the selection process or subjects that are too represented in the sample [21]. The first step to conduct this research is started with a pilot test, and it tested approximately 40 people. According to [22] Range of 1 until 6 in Likert scale will be used in the questionnaire. The range has been choosing to avoid safe selection or known as the middle selection.

\section{Statistical Analysis of Data}

The validity test that using Pearson correlation shows that all of the items are valid with significant at $p<0.01$ [23]. Based on table 5.1 above result of Pearson correlation for each variable shows with the significant rate at 0,000 level with product appearance at 0.687 , location 0.688 , the price at 0.644 , variation 0.723 , brand appearance at 0.679 , and service 0.754 .

TABLE 1. VALIDITY TEST

\begin{tabular}{c|c|c}
\hline Variable & Pearson Correlation & Sig. (2-tailed) \\
\hline Quality product & 0.687 & 0.000 \\
\hline Location & 0.688 & 0.000 \\
\hline Price & 0.664 & 0.000 \\
\hline Variation & 0.723 & 0.000 \\
\hline Brand appearance & 0.679 & 0.000 \\
\hline Service & 0.754 & 0.000 \\
\hline
\end{tabular}

Result of the reliability test above shows that the data that have been collected and analysis is reliable. According to [24] Cronbach Alpha coefficient is the most commonly used for internal consistency. By using Cronbach's alpha for this study, reliability test shows at 0.789 with the total of items are 6. If the Cronbach's alpha is equal to or greater than 0.600 , the data is reliable enough to be analyzed [25].

TABLE 2. RELIABILITY TEST

\begin{tabular}{c|c}
\hline Cronbach's Alpha & N of items \\
\hline 0.789 & 6 \\
\hline
\end{tabular}

\section{a. Mean Analysis}

Mean analysis in this research used to generates and get the information about the ideal satay Taichan product based on consumer perception in Bandung. Based on the table shows in 5.3, the highest score of mean analysis result using SPSS is quality of product and price with total mean is (5.18) and (5.10) which is not significantly different from both of the aspect. Sorted from the highest to the lowest score, there is slight difference between three other aspects which are service in the third place with a total mean (4.69) followed by location and variation in fourth and fifth place with the mean score is (4.62) and (4.21). it means that people still consider and paying attention on service provided, reachable location, and variance of the product offered. Meanwhile, brand appearance appeared with the lowest score, which is only (3.89). From the result of mean analysis above we can see that most of the consumer perception in choosing satay Taichan product is the quality of the product as a priority to purchase or buy satay Taichan product. In order to support the quality of the product to meet the consumer, perception is price. Hence, consumer perceptions on purchasing satay Taichan product is good quality of the product that meet the ideal price of its product. 
TABLE 3. MEAN ANALYSIS

\begin{tabular}{|c|c|c|c|c|c|c|c|c|c|}
\hline \multirow[t]{2}{*}{ No } & \multirow[t]{2}{*}{ Label } & \multicolumn{6}{|c|}{ Response Frequency } & \multirow[t]{2}{*}{ Total } & \multirow[t]{2}{*}{ Mean } \\
\hline & & 1 & 2 & 3 & 4 & 5 & 6 & & \\
\hline \multirow[t]{2}{*}{1} & $\begin{array}{l}\text { Quality } \\
\text { product }\end{array}$ & 5 & 3 & 1 & 17 & 83 & 83 & 192 & 5.18 \\
\hline & & $2.6 \%$ & $1.6 \%$ & $5 \%$ & $8.9 \%$ & $43.2 \%$ & $43.2 \%$ & $100 \%$ & \\
\hline \multirow[t]{2}{*}{2} & Location & 3 & 4 & 15 & 54 & 80 & 36 & 192 & 4.62 \\
\hline & & $1.6 \%$ & $2.1 \%$ & $7.8 \%$ & $28.1 \%$ & $41.7 \%$ & $18.8 \%$ & $100 \%$ & \\
\hline \multirow[t]{2}{*}{3} & Price & 4 & 2 & 2 & 31 & 76 & 77 & 192 & 5.10 \\
\hline & & $2.1 \%$ & $1 \%$ & $1 \%$ & $16.1 \%$ & $39.6 \%$ & $40.1 \%$ & $100 \%$ & \\
\hline \multirow[t]{2}{*}{4} & Variation & 5 & 8 & 36 & 62 & 55 & 26 & 192 & 4.21 \\
\hline & & $2.6 \%$ & $4.2 \%$ & $18.8 \%$ & $32.3 \%$ & $28.6 \%$ & $13.5 \%$ & $100 \%$ & \\
\hline \multirow[t]{2}{*}{5} & $\begin{array}{l}\text { Brand } \\
\text { appearance }\end{array}$ & 9 & 18 & 38 & 66 & 43 & 18 & 192 & 3.89 \\
\hline & & $4.7 \%$ & $9.4 \%$ & $19.8 \%$ & $34.4 \%$ & $22.4 \%$ & $9.4 \%$ & $100 \%$ & \\
\hline \multirow[t]{2}{*}{6} & Service & 5 & 8 & 12 & 44 & 70 & 53 & 192 & 4.69 \\
\hline & & $2.6 \%$ & $4.2 \%$ & $6.3 \%$ & $22.9 \%$ & $36.5 \%$ & $27.6 \%$ & $100 \%$ & \\
\hline
\end{tabular}

b. Mode Analysis

TABLE 4. MODE ANALYSIS

\begin{tabular}{c|c|c|c|c|c|c}
\hline & $\begin{array}{c}\text { Quality } \\
\text { product }\end{array}$ & Location & Price & Variation & $\begin{array}{c}\text { Brand } \\
\text { appearance }\end{array}$ & Service \\
\hline Mode & 5 & 5 & 6 & 4 & 4 & 5 \\
\hline
\end{tabular}

To support the findings of mean analysis above is used mode analysis that is also analyzed by using SPSS. The highest score from the result of mode analysis is price (6). Followed by service, location, and quality of product with total mode is (5). However, brand appearance and variation only get (4) from the total mode. Result of mode analysis below shows that consumer still considers

\section{c. Consumer Product and Price Consciousness}

One of the consumer interest while purchasing satay Taichan product is availability of Taichan product variance. Based on the pie chart above, consumer shows the tendency in choosing variance of Taichan product is sate kulit with total percentage is $81.90 \%$. Second is sate usus with $31.60 \%$ followed by sate telur with $30.60 \%$ and the lowest is sate bakso with only $17.60 \%$. It means that besides only purchasing breast chicken satay of Taichan, consumer also willing to buy another variance of Taichan product such as sate kulit, sate usus, sate telur, and sate bakso. the price as the main perception in purchasing satay Taichan product, but they still contemplate about the quality of product and location. Providing strategic location with a good quality of raw material will giving consumer good perceptions on purchasing satay Taichan, with support of variation in Taichan product and brand appearance itself.

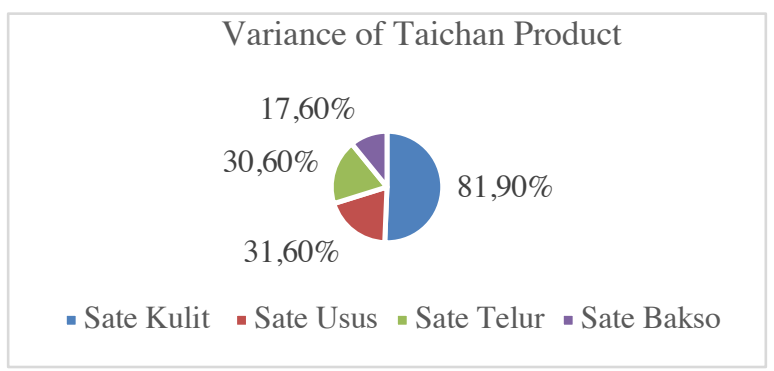

Fig.1 Consumer Product Consciousness

Consumer consciousness to pay on satay Taichan product based on table 5.5 above shows that most of them are usually and generally spend about $20.000-30.000$ rupiah to purchase Taichan product with a total of percentage from the research are $40.3 \%$. Beside that spending money on Taichan product 
with a range of 30.000-40.000 rupiah still comprehend by the consumer with a total percentage is $28.8 \%$. However, the

lowest spend of 10.000-20.000 rupiahs and highest spend more than 40.000 get slightly difference with the total of percentage, only $16.2 \%$ and $14.7 \%$.

TABLE 5. PRICE CONSCIOUSNESS

\begin{tabular}{c|c|c|c}
\hline $\mathrm{Rp} 10.000-20.000$ & $\mathrm{Rp} 20.000-30.000$ & $\mathrm{Rp} 30.000-40.000$ & $>\mathrm{Rp} 40.000$ \\
\hline $16,2 \%$ & $40,3 \%$ & $28,8 \%$ & $14,7 \%$ \\
\hline
\end{tabular}

\section{d. Consumer perception toward satay Taichan product}

TABLE 6. CONSUMER PRICE PERCEPTION TOWARD TAICHAN PACKAGE OF SANTUY PROJECT

\begin{tabular}{|c|c|c|c|c|}
\hline No. & Package & Tendency & Price & Percentage \\
\hline \multirow{4}{*}{1.} & \multirow{4}{*}{$\begin{array}{c}\text { Satay Taichan }+ \\
\text { Gulai sauces + Nasi }\end{array}$} & \multirow{4}{*}{$56,2 \%$} & $15.000-20.000$ & $57,1 \%$ \\
\hline & & & $21.000-30.000$ & $38,7 \%$ \\
\hline & & & $31.000-40.000$ & $4,2 \%$ \\
\hline & & & $>40.000$ & - \\
\hline \multirow{4}{*}{2.} & \multirow{4}{*}{$\begin{array}{c}\text { Satay Taichan }+ \\
\text { Opor sauces + Nasi }\end{array}$} & \multirow{4}{*}{$43,8 \%$} & $15.000-20.000$ & $57,6 \%$ \\
\hline & & & $21.000-30.000$ & $38,7 \%$ \\
\hline & & & $31.000-40.000$ & $3,7 \%$ \\
\hline & & & $>40.000$ & - \\
\hline
\end{tabular}

The tendency of consumer toward price perception is used to generate cash flow projection scenarios. By given consumer two choices of packages with different spices which are opor and gulai, respondent tendency below in table 5.6 shows that Taichan package with gulai sauces is more dominant with an average of tendency $56.2 \%$. Meanwhile, the rest of them likely to choose Taichan package with opor sauces proven by the total of tendency about $43.8 \%$. Based on the result of price perception below, it can be seen that a suitable price for a package of Taichan product with gulai or opor sauces is in the range of 15.000-20.000 rupiahs. However, the price can still be raised up to a value of 20.000-30.000 rupiahs based on the result of price perceptions from the survey result below. The result of all the price toward consumer perception will be used to generate a revenue forecast.
Santuy Project general expense and operation needs such as equipment, administrative expense, rent space, cart, raw material and salary and wages, which then will generate as a cash-out in cash flow forecasting. In order to support the business and fulfill the needs of the company, initial investment will be used to start the business. The combination of projected cash in and cash out generate the differences of three scenarios. To make the scenarios are suitable enough and produced positive cash flow, general expense need to be modified.

\section{e. Cash Flow Forecasting Scenarios}

TABLE 7. CASH FLOW FORECASTING SCENARIOS

\begin{tabular}{c|cr|rr|rr}
\hline Year & \multicolumn{2}{|c|}{ Best Scenario } & \multicolumn{2}{c|}{ Normal Scenario } & \multicolumn{2}{c}{ Worst Scenario } \\
\hline $\mathbf{0}$ & IDR & $(182,400,000)$ & IDR & $(131,856,000)$ & IDR & $(106,584,000)$ \\
\hline $\mathbf{1}$ & IDR & $126,500,000$ & IDR & $65,574,000$ & IDR & 581,000 \\
\hline $\mathbf{2}$ & IDR & $319,416,000$ & IDR & $176,532,000$ & IDR & $24,528,000$ \\
\hline $\mathbf{3}$ & IDR & $591,527,000$ & IDR & $336,897,000$ & IDR & $67,826,000$ \\
\hline $\mathbf{4}$ & IDR & $970,410,000$ & IDR & $565,143,000$ & IDR & $137,543,750$ \\
\hline $\mathbf{5}$ & IDR & $1,494,171,200$ & IDR & $885,060,200$ & IDR & $243,249,638$ \\
\hline
\end{tabular}

The tendency of consumer perceptions through the price of Santuy packages is used to calculate the assumption of cashflow forecasting above. Sales revenue projection produced from consumer perception toward price and an average total of sales package in a year.
Based on Table 5.8 above shows the NPV (Net Present Value) is accepted in three scenarios which are best, normal, and worst scenario. The NPV rules is accepted and reliable to be invested if the NPV is positive $(>0)[26]$. In the other hand, 
IRR (Internal Rate of Return) is rationale when its greater than the discounted rate of WACC (weighted average cost of capital) [27]. Result of IRR above is acceptable because it is greater than WACC value which is $(17,57 \%)$. The weighted average cost of capital is obtained from the calculation of risk-free rate on Indonesia, expected market return, and a beta of the industry. Because there is no debt in this company, the cost of capital will be calculated using CAPM (Capital Asset Pricing Model) method

TABLE 8. NPV, IRR, AND PAYBACK PERIOD SCENARIO

\begin{tabular}{|c|c|c|c|c|c|c|}
\hline \multirow[b]{2}{*}{ NPV } & \multicolumn{2}{|c|}{ Best Scenario } & \multicolumn{2}{|c|}{ Normal Scenario } & \multicolumn{2}{|c|}{ Worst Scenario } \\
\hline & IDR & $1,693,614,876$ & IDR & $949,026,715$ & IDR & $133,978,723$ \\
\hline IRR & & $149 \%$ & & $125 \%$ & & $44 \%$ \\
\hline Payback Period & $1 \mathrm{y}$ & $\mathrm{r}$ and 1 month & 1 ye & and 3 months & 5 ye & and 3 months \\
\hline
\end{tabular}

\section{CONCLUSION AND DISCUSSION}

Based on the result of this research, there are several to reach the awareness of consumer toward Santuy Project product. To meet the consumer expectation toward the quality of the product, satay Taichan culinary industry should consider price allocation, which is needed to be prioritized on quality of raw material and ingredients.

Besides that, other supporting factors to gain the consumer awareness are variation. It can be determined to add a new menu for Taichan product that suitable with consumer perceptions such as sate kulit, sate bakso, sate usus, and sate telur. To gain more attention from the consumer by providing satisfying services and reachable location will also affect to the consumer awareness and brand appearance can be the other supporting factors to raise the awareness as its get the lowest score to be considered by the consumer to purchase Taichan product.

By knowing the consumer price perception through Taichan satay product, Santuy can calculate the budgeting efficiency for the next five years of capital needs. By calculating and knowing the capital budgeting efficiency, Santuy will able to reach the ideal IRR (Internal Rate of Return) and Payback Period.

This research is able to replicate for the next five years so that can identify the consumer perceptions more accurate toward the culinary industry for the next five years. This analysis has to be revived as a result of there may well be a totally different state of affairs and several other changes within the future. This analysis is often conducted in different location and area to understand consumer perceptions toward culinary industry in another area.

\section{REFERENCES}

[1] A. Pramono, Lezatnya Bisnis Kuliner, Jakarta : Gramedia Pustaka Utama, 2014.

[2] K. G. Grunert, H. H. Larsen, T. K. Madsen and A. Baadsgaard, Market Orientation in Food and Agriculture, Springer US, 1996.

[3] T. S. Liao and R. John, "Innovation Investments, Market Engagement and Financial Performance: A Study among Australian Manufacturing SMEs," Research Policy, pp. 117-125, 2010.

[4] K. E. Clow and D. W. Vorhies, "Building a competitive advangtage for service firms: Measurement of customer expectation of service quality," Journal of Services Marketing, pp. 22-32, 1993.
[5] S. Atkinson, The Business Book, London: Dorling Kinderlsey Limited , 2014.

[6] D. V. Kousenidis, "A free cash flow version of the cash flow statement: a note," Managerial finance, pp. 645-643, 2006.

[7] P. C. Mark T. Chen, "ABC of Cash Flow Projections," AACE International Transactions, pp. PM. 02.1 - PM. 02.5, 2007.

[8] R. Rajendra, the handbook of global corporate treasury, Singapore : John Wiley and Sons , 2013

[9] M. Cristina, "Characteristic of the consumer preference reserach process," p. 2, 2013.

[10] K. L. Keller, "Conceptualizing, Measuring, and Managing Customer-Based Brand Equity," Journal of Marketing, pp. 1-22, 2013.

[11] J. W. M. Orville C. Walker Jr, Marketing Strategy, Mew York: Mc Graw Hill, 2008.

[12] K. G. Grunert, "current issues in the understanding of consumer food choice," Trends in food science and technology, pp. 275-285, 2002 .

[13] R. Navon, "Construction Management and Economics," Resourcebased model for automatic cash flow forecasting, pp. 501-510, 1995.

[14] Bradford D. Jordan, Randolph W. Westerfield, Stephen A. Ross, Fundamental of Corporate Finance, New York: Mc Graw Hill, 2010.

[15] Westerfield, Fundamental of Corporate Finance, New York, 2010.

[16] S. A. Ross, Funadamental of Corporate Finance, New York: McGraw-Hill , 2010.

[17] A. Bryan and E. Bell, Business Research Method, vol. IV, USA : Oxford University Press , 2015.

[18] G. D. Israel, "Determining Sample Size : University of Florida Coorperation Extention Service," 1992.

[19] J. J. Tejada and J. R. B. Punzalan, "On the Misuse of Slovin's Formula," Journal of Business and Management , pp. 901-912, 2015.

[20] K. Saumure and L. M. Given, "Convenience Sample," The SAGE Encyclopedia of Qualitative Research Methods, 2008.

[21] I. Etikan, "Comparison of Convenience Sampling and Purposive Sampling," Research Gate , pp. 2-4, 2016.

[22] R. Dhar and I. Simonson, "The Effect of Force Choice on Choice," Journal of Marketing Reseacrh, vol. 40, pp. 146-160, 52003.

[23] A. Field, Discovering Statistic Using SPSS, London: SAGE Publication, 2009.

[24] B. E. Whitley, Principles of Research in Behavioral Science, Boston: McGraw Hill, 2002.

[25] D. Straub, M. C. Boudreau and D. Gefen, "Validation Guidelines for IS Positivist Research," Communication of the Association for Information System, pp. 13, 340-487, 2004.

[26] D. Kahneman and D. T. Miler, "Norm Theory: Comparing Reality to Its Alternatives," Psychological Review , pp. 93 (2), 136-135, 1986.

[27] H. Belyadi and F. Belyadi, "Economic Valuation," Science Direct, pp. 207-261, 2017. 


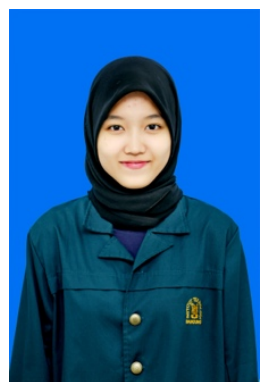

Alya A. Rohali got her bachelor's degree in School of Business and Management, Bandung Institute of Technology. During her study, Alya conducted several business plan and project. Currently, she is in the final year of university and doing her final project.

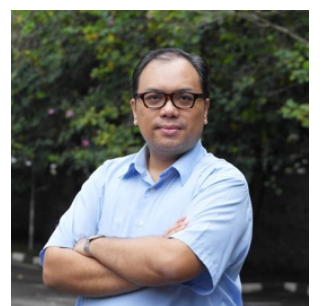

R. A, Rahadi has direct experience working for 15 (fifteen)years in real estate, property, architecture, design, investment management, financial consulting, and research industry. Holds a bachelor degree in Architecture Engineering from Bandung Institute of Technology, hold two master degrees in Management from Swiss German University, Indonesia and in Business Administration from Fachhochuschule Konstaz - Hochschule fur Technik, Wirtscaft und Gestaltung, Germany, holds a Doctorate degree in Management Science from School of Business and Management, Bandung Institute of Technology. 